\title{
オトガイ下引き抜き法を用いて気道管理を行った 顔面骨骨折手術の麻酔経験
}

\section{大石悠理 ${ }^{* 1}$ 菊地佳枝 ${ }^{* 1}$ 東南杏香*2 佐牟田 健 ${ }^{* 1}$}

[要旨] 顔面骨骨折の手術において, 通常の経口・経鼻挿管が手術操作の妨げになることがある. その場合は一般的に気管切開術が選択されるが, オトガイ下引き抜き法が選択されることもある. オトガイ下引き抜き法は良好な視野を確保し，咬合を確認しながら手術操作を進めるのに有用な気 道確保方法である. 2015年 12月以降に当院では 10例の顔面骨骨折の手術に対して，オトガイ 下引き抜き法による気道確保を施行した. いすれれも合併症なく施行することができた. オトガイ下 引き抜き法は気管切開による重篤な合併症を避けることができる. 顔面骨骨折手術の気道確保方法 として有用であると考えた.

キーワード : オトガイ下引き抜き法, 顔面骨骨折, 気道確保

\section{はじめに}

顔面骨骨折手術において，気道確保方法が問題と なることがある。通常の経口挿管が手術操作の妨げ になる場合には，まず経鼻挿管を選択する。しかし， 経鼻挿管ではチューブによる骨片変位や鼻出血が起 こることがあり，選択しにくい．また髄液漏・頭蓋 骨骨折の症例では禁忌となる。経口挿管も経鼻挿管 も選択できない場合は，一般的には気管切開が選択 されるが，オトガイ下引き抜き法が選択されること もある。 2015 年 12 月以降に当院でオトガイ下引き 抜き法を用いて気道管理を行った症例について報告 する。

なお本発表において，当院の倫理委員会に則り， 患者からは書面により同意を得ている。

\section{Iオトガイ下引き抜き法}

オトガイ下引き抜き法は1986年に Altemirによ つて初めて報告された ${ }^{1)}$. 通常の経口挿管を施行後, オトガイ下から口腔底へ貫通させた創部よりオトガ イ下へ気管チューブを引き抜く気道確保方法であ る。当院では以下の手順で施行している(図1)。ま ず，麻酔科医が通常の経口挿管を行う。次いで執刀 医がオトガイ下を切開する。オトガイ下の切開線か ら鉗子を舌側面に沿わせるように進めて，舌下腺， ワルトン管，舌神経を損傷しないように注意しなが ら，口腔底へ貫通させる。気管チューブのスリップ ジョイントを外して，まず脱気したパイロットカフ を引き抜き，続いて気管チューブを引き抜く。この ときチューブは下顎骨内面口腔組織(舌下腺, ワル トン管，舌神経)との間に位置する。チューブを糸
*1 神戸赤十字病院麻酔科

22 神戸大学医学部附属病院麻酔科
受理日 2017. 4. 30 . 採択日 2017. 7. 13 .
著者連絡先 大石悠理

干 651-0073 兵庫県神戸市中央区脇浜海岸通 1-3-1 神戸赤十字病院麻酔科 

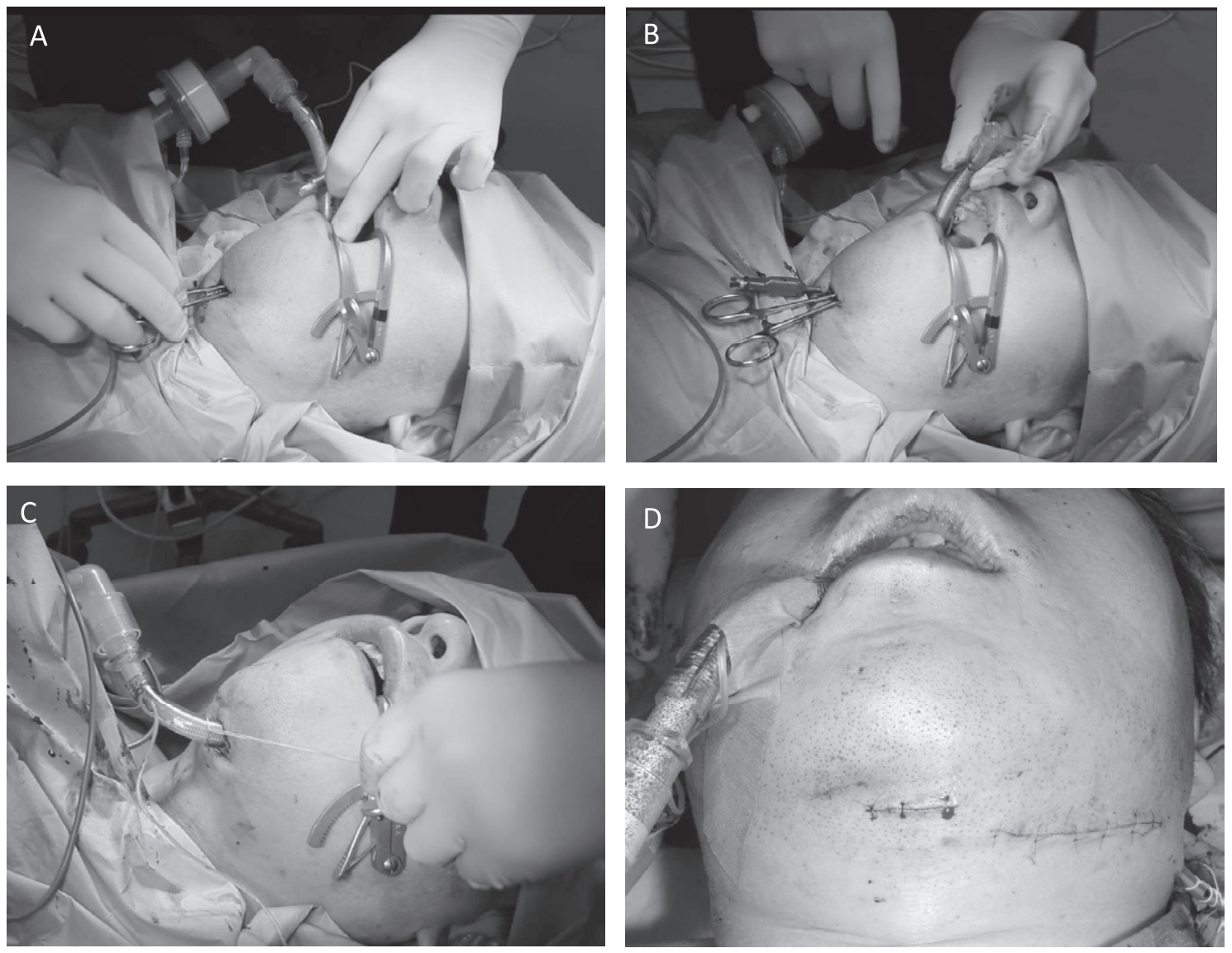

図1 オトガイ下引き抜き法の手技
$\mathrm{A}$ : 鉗子を口腔底へ貫通
$\mathrm{B}$ ：気管チューブの引き抜き
$\mathrm{C}$ ：気管チューブの固定
$\mathrm{D}$ ：創は約 $1.5 \mathrm{~cm}$

で皮膚に固定する。その後, 麻酔科医が聴診や呼吸 器設定で換気状態を確認して，さらに場合によって は McGRATH ${ }^{\circledR}$ MAC や気管支ファイバーを使用し て気管チューブの位置を確認する。術野を消毒して 観血的整復術を施行する。術後に気管チューブを再 度口腔内へ戻す。術後の抜管は通常の手術と同様に 評価をして行う。オトガイ下引き抜き法に所要する 時間は，閉創も含めて約 $10 \sim 15$ 分である.

\section{II 症 例}

2015 年 12 月から 2016 年 12 月までに当院でオトガ イ下引き抜き法により気道確保を施行した症例は 10
例で女性 1名，男性 9名であった(表 1)。指管のデバ イスは麻酔担当医に一任された。通常の喉頭鏡が1 例, エアウェイスコープ®(AWS)が2例, McGRATH ${ }^{\circledR}$ MACが7例であった。スリップジョイントが外れ る挿管チューブが必要であり, 症例 1 から症例 7 ま ではファストラック用のチューブを使用した。症例 8はカフリークが多く, 通常のスパイラルチューブ を使用して，スリップジョイント部で切断しファス トラック用のスリップジョイントを使用した。症例 9，10はスリップジョイント部が外れるスパイラル チューブを使用した。すべての症例で，手術室で抜 管を行い，特に合併症なく施行することができた。 
表 1 症例

\begin{tabular}{|c|c|c|c|c|}
\hline 症例 & 年齢・性 & 骨折部位 & 頭蓋底骨折 & 挿管デバイス \\
\hline 1 & 68 女 & 上顎(右 LF I，左 LF I + II) & あり & AWS \\
\hline 2 & 76 & 上顎 (左 LF I, 矢状)，下顎 (オトガイ部・両関節突起) & なし & AWS \\
\hline 3 & 68 & 上顎 (LF II) & あり & McGRATH $^{\circledR}$ \\
\hline 4 & 54 & 上顎 (LF I ) & なし & McGRATH $^{\circledR}$ \\
\hline 5 & 41 男 & 上顎骨折 (右 LF I, 左 LF II) ·左㚘具 & あり & McGRATH $^{\circledR}$ \\
\hline 6 & 34 & 下顎骨折・右㚘喟 & なし & McGRATH $^{\circledR}$ \\
\hline 7 & 43 & 上顎 (LF I + II) - 左㚘盈 & あり & 喉頭鏡 \\
\hline 8 & 42 & 右㚘買・オトガイ・両側関節突起 & なし & McGRATH $^{\circledR}$ \\
\hline 9 & 30 & 上顎骨折 (LF I )・鼻骨骨折 & なし & McGRATH $^{\circledR}$ \\
\hline 10 & 24 男 & 下顎骨，右㚘骨 & あり & McGRATH $^{\circledR}$ \\
\hline
\end{tabular}

LF : Le Fort, AWS : エアウェイスコープ, McGRATH ${ }^{\circledR}: \mathrm{McGRATH}^{\circledR} \mathrm{MAC}$

経口摂取は術翌日から開始し，退院後の経過も良好 である。

\section{III 考 察}

顔面骨骨折手術において，気道確保方法が問題と なることがある。通常の経口挿管では顎間固定や咬 合の確認が困難な場合である。その際はまず経鼻挿 管が選択されるが，経鼻挿管ではチューブによる骨 片変位や鼻出血が起こることがある。また髄液漏・ 頭蓋骨骨折の症例では禁忌となる。経口抻管も経鼻 挿管も選択できない場合には，一般的には気管切開 が選択される。しかし気管切開では気管孔の閉鎖に は週単位の時間がかかり, 気管狭窄や気管食道瘻な どの重篤な合併症がある。また目立つ瘢痕も問題と なる。そのため気管切開に伴う合併症を避けるため, 術中のみの気道確保を必要とし, 経口抻管・経鼻挿 管が不適な場合には，オトガイ下引き抜き法による 気道確保が選択肢としてあがる。

オトガイ下引き抜き法における合併症として，い くつか報告されている. 第一に舌下腺・顎下腺や舌 神経損傷である ${ }^{2)}$ 。これは下顎骨に沿わせて正中で 貫通させることで防ぐことができるといわれてい る。第二に瘻孔形成や粘液囊胞，創部感染である. 創部感染はオトガイ下引き抜き法における合併症で 最も多いと報告されている2),3)。しかし報告ではす べて局所処置で改善している，血液や軟部組織がチ
ューブ内に入らないようにするためチューブ先端に 外科手袋の指先の部位をかぶせて引き抜く工夫を行 つている報告もある ${ }^{4)}$ 第三に気管チューブの誤抜 去や片肺挿管がある ${ }^{2)}$ 3). 5)。これは麻酔科側で最も 問題となる合併症である。当院では引き抜きの際に はしっかりと口腔側のチューブを保持し，引き抜き 後にはチューブを糸で皮膚に固定しておく。引き抜 き後の両肺の呼吸音を確認することに加えて，気管 支ファイバーやMcGRATH ${ }^{\circledR} \mathrm{MAC}$ を使用して，気 管内や口腔内のチューブ位置を確認している。

この方法はチューブを引き抜く際に，スリップジ ヨイント部位を外す必要がある。当初はファストラ ック用のチューブを使用していた。しかし，カフリ ークが多く，ガーゼパッキングで対応することも多 かった，症例数増加に伴い，スリップジョイントが 外れるスパイラルチューブを新規採用し, 症例 9 以 降では使用するようになった。 スリップジョイント が外れないチューブを使用する際には，新たなチュ ーブをオトガイ下の切開創から口腔内に貫通させ て，既存の抻管チューブと入れ替える方法も報告さ れている ${ }^{5)}$. 当院では脱気したパイロットカフと気 管チューブを同時に引き抜くと，組織の挫滅が大き くなると考えて, 別々に引き抜いている。そその際に， 脱気したパイロットカフと気管チューブが違う経路 で出てくる場合があるため, 切開創を貫通する際に, 鉗子でしっかりと広げておく必要がある。 
オトガイ下の切開線は約 $1.5 \mathrm{~cm}$ (図 1) と小さく, 術 後の疼痛は強くない，通常は骨折整復部位の疼痛の 方が強い. そのため整復部位に対する鎮痛処置にて カバーできる. 術後の経口摂取は整復部位の疼痛に 応じて可能であり，オトガイ下引き抜き法を選択し たことによる経口摂取の延期は認めなかった。

また今回，すべての症例で手術室抜管が可能であ つた。 あらかじめ気管挿管をされている場合や，頭 部外傷を併発して意識障害を伴うなど, 術後も人工 呼吸管理の継続が予想される場合は, 当院ではオト ガイ下引き抜き法は選択していない. 術後もオトガ イ下引き抜き法のまま気道管理をする報告もある が2), 長期間留置による感染のリスクについては不 明である。

\section{結＼cjkstart語}

気道確保方法が問題となる顔面骨骨折手術におい て，オトガイ下引き抜き法を用いて気道確保を行っ た。チューブ誤抜去などの危険性もあるため執刀医 と協力して施行し，引き抜き前後は，気管内や口腔
内のチューブ位置を確認する必要がある。

本論文の要旨は日本臨床麻酔学会第 36 回大会 (2016年，高知市)にて発表した。

\section{参考文献}

1) Altemir $\mathrm{FH}$ : The submental route for endotracheal intubation. A new technique. J Maxillofac Surg 14: 64-65, 1986

2) Das S, Das TP, Ghosh PS : Submental intubation : A journey over the last 25 years. J Anaesthesiol Clin Pharmacol $28: 291-303,2012$

3) Kita R, Kikuta T, Takahashi M, et al. : Efficacy and complications of submental tracheal intubation compared with tracheostomy in maxillofacial trauma patients. J Oral Sci 58 : 23-28, 2016

4) Lima SM Jr, Asprino L, Moreira RW, et al. : A retrospective analysis of submental intubation in maxillofacial trauma patients. J Oral Maxillofac Surg $69: 2001-$ 2005, 2011

5) Amin M, Dill-Russell P, Manisali M, et al. : Facial fractures and submental tracheal intubation. Anaesthesia $57: 1195-1199,2002$

\title{
Submental Tracheal Intubation in Maxillofacial Trauma Patients
}

\author{
Yuri OISHI ${ }^{* 1}$, Yoshie KIKUCHI*1, Momoka TONAN*2, Takeshi SAMUTA*1 \\ ${ }^{* 1}$ Department of Anesthesiology, Kobe Red Cross Hospital \\ ${ }^{* 2}$ Division of Anesthesiology, Department of Surgery Related, Kobe University Graduate School of Medicine
}

Oral and nasal intubation sometimes interferes with surgical procedures in maxillofacial trauma patients. In these cases, tracheostomy is usually selected for airway management. Submental tracheal intubation is an effective alternative to oral and nasal tracheal intubation or tracheostomy. Submental tracheal intubation provides a good view and correct articulation. Ten patients underwent submental tracheal intubation without complications since December 2015 at our hospital. Submental tracheal intubation avoids the severe complications of tracheostomy. Submental tracheal intubation is useful as an airway management surgical procedure in maxillofacial trauma patients.

Key Words : Submental tracheal intubation, Maxillofacial trauma, Airway management 